\title{
ZAKUP KSIĄŻEK PRZEZ BIBLIOTEKĘ TEOLOGICZNĄ UNIWERSYTETU ŚLĄSKIEGO
}

Gromadzenie to proces pozyskiwania i uzupełniania zbiorów bibliotecznych według przyjętych zasad oraz zgodnie z ustaloną polityką i specjalizacją. Odbywa się drogą zakupu, wymiany, darów i egzemplarza obowiązkowego, otrzymywanego przez biblioteki $\mathrm{w}$ komplecie lub $\mathrm{w}$ wyborze ${ }^{1}$. W artykule poddano analizie kwestie dotyczące zakupu naukowej literatury polskiej oraz zagranicznej, prowadzonego przez Bibliotekę Teologiczną Uniwersytetu Śląskiego w Katowicach.

Dotychczas zagadnienia związane z problematyką nabywania publikacji przez biblioteki były podejmowane w literaturze przedmiotu głównie przy okazji omawiania zasad i sposobów gromadzenia zbiorów ${ }^{2}$.

* Agata Muc - mgr bibliotekoznawstwa i informacji naukowej, bibliotekarz w Bibliotece Teologicznej Uniwersytetu Śląskiego w Katowicach.

${ }^{1}$ Por. Encyklopedia wiedzy o ksiażce, Wrocław 1971, s. 838-839; Encyklopedia wspótczesnego bibliotekarstwa polskiego, Wrocław 1976, s. 131-132; Stownik terminologiczny informacji naukowej, Wrocław 1979, s. 49; Bibliotekarstwo, red. Z. Żmigrodzki, Warszawa 1998, s. 54-59.

${ }^{2}$ L. Biliński, Zakup ksiażek - depozyty - zamówienia publiczne, „Poradnik Bibliotekarza”, 2 (2004), s. 3-5; M. Ciesielska, Gromadzenie zbiorów w bibliotekach pedagogicznych - wyniki ankiety, „Bibliotekarz”, 7-8 (2003) s. 27-30; J. Dunin, W sprawie aktualnych problemów gromadzenia bibliotecznego, „Przegląd Biblioteczny”, 1 (1998) s. 17-29; R. Dunin, Gromadzenie Druków Zwartych w Bibliotece Gtównej PAT, „FIDES - Biuletyn Bibliotek Kościelnych”, 1(14) 2002, s. 95103; E. Grala, Metodyka opracowania zasad gromadzenia zbiorów w bibliotekach Stanów Zjednoczonych, „Przegląd Biblioteczny”, 2/3 (1996) s. 143-157; W. Michalski, Oddział gromadzenia i uzupetniania zbiorów w latach 1944-1977, „Archiwa Biblioteki i Muzea Kościelne”(dalej: ABMK), 23 (1971) s. 69-79; A. Mieżęcki, Gromadzenie piśmiennictwa naukowego w bibliotekach sieci Polskiej Akademii Nauk, „Przegląd Biblioteczny”, 1 (1987) s. 45-54; A. Olejnik, Wybrane zagadnienia gromadzenia zbiorów w Bibliotece Polskiej Akademii Nauk w Warszawie, „Przegląd Biblioteczny”, 2 (1984) s. 245-248; T. Szpakowska, Gromadzenie ksiegozbioru bibliotecznego po wejściu ustawy o egzemplarzu obowiazkowym dla Biblioteki KUL, ABMK, 77 (2002) s. 19-22; J. Szulc, Gromadzenie i uzupetnianie księgozbioru w bibliotekach kościelnych w Polsce, „FIDES Biuletyn Bibliotek Kościelnych", 2 (1998) s. 65-68; R. Zwierzyńska, Gromadzenie zbiorów w bi bliotece pedagogicznej: teoria i praktyka, „Bibliotekarz”, 2 (2002) s. 15-16; E. Żelechowska, 
Zakup książek przez Bibliotekę Teologiczna, obok wymiany ${ }^{3}$ i darów, jest drugą co do wielkości formą uzupełniania zbiorów i stanowi w przybliżeniu $31 \%$ wszystkich dotychczasowych wpływów.

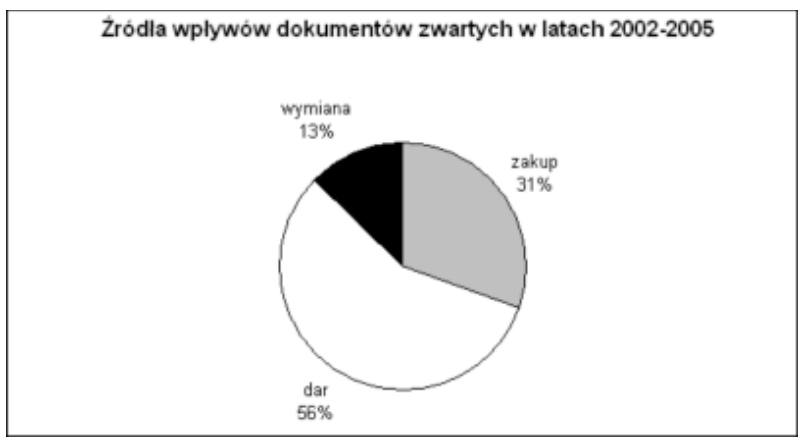

\section{Finansowanie zakupu}

Zakup literatury przez Bibliotekę Teologiczną jest uwarunkowany dwoma różnymi źródłami finansowania. Większość środków jakimi dysponuje Biblioteka pochodzi z Kurii Metropolitalnej w Katowicach ${ }^{4}$. Pozostałe fundusze trafiają z Uniwersytetu Śląskiego z puli przeznaczanej na badania statutowe i własne. Dotychczas blisko $80 \%$ wszystkich środków przeznaczanych na uzupełnianie księgozbioru pochodziło z Kurii Metropolitalnej.

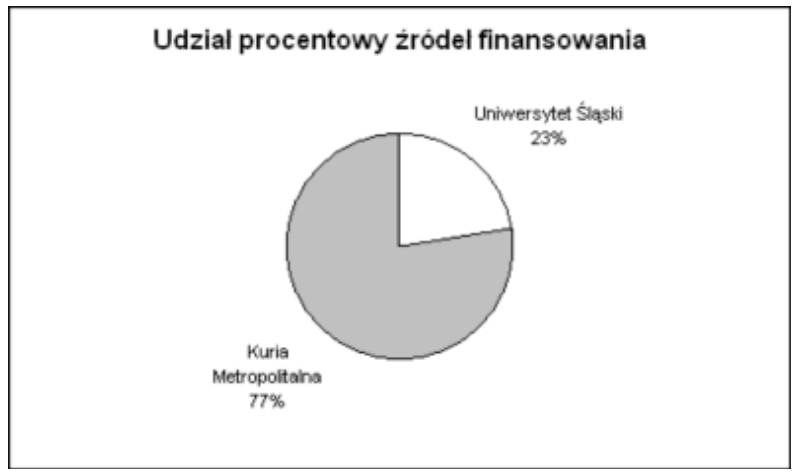

Funkcjonowanie działu gromadzenia, ABMK, 62 (1993) s. 195-206; Z. Żmigrodzki, «Obyś zbiory gromadzit» - dylematy czasu obecnego, „Przegląd Biblioteczny”, 1 (1998) s. 31-37.

${ }^{3}$ Więcej na temat wymiany publikacji zob. E. Olszowy, Wymiana krajowa $w$ Bibliotece Teologicznej Uniwersytetu Ślaskiego", ABMK, 82 (2005) s. 177-186.

${ }^{4}$ Biblioteka Teologiczna Uniwersytetu Śląskiego, Umowa użyczenia zawarta w dniu 1 września 2001 roku pomiędzy Archidiecezja Katowickq a Uniwersytetem Ślqskim w Katowicach [rkps]. 
Kwota uzyskana z Uniwersytetu, początkowo niewielka, obecnie wykazuje tendencję wzrostową, co świadczy o rozwoju badań naukowych prowadzonych na Wydziale Teologicznym. Wielkość dokonywanych zakupów dokumentów w poszczególnych latach ilustruje poniższy wykres.

\section{ZAKUP}

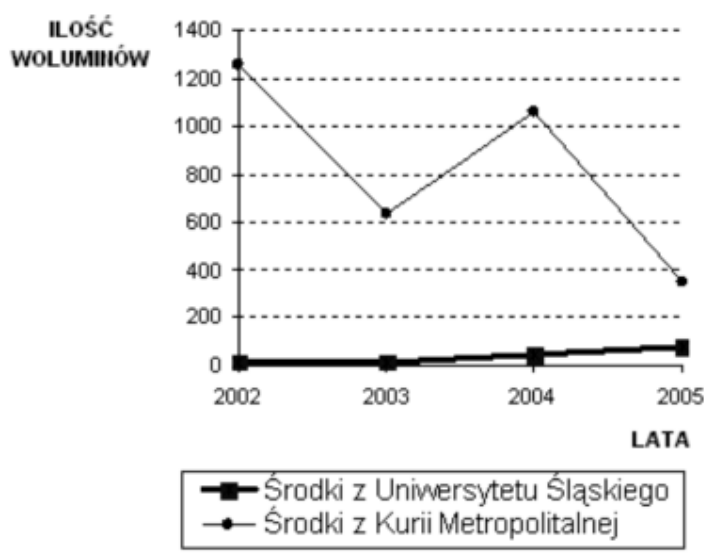

Zakres tematyczny prac naukowych powstających na Wydziale w znacznym stopniu determinuje profil zakupów dokonywanych ze środków uniwersyteckich. Główny zrąb księgozbioru stanowią pozycje specjalistyczne odnoszące się do historii Kościoła, ze szczególnym uwzględnieniem Kościoła na Śląsku, patrologii, biblistyki, etyki, psychologii, ekumenizmu czy liturgiki. Dużą część spośród tych książek stanowi wąskospecjalistyczna literatura zagraniczna, która zwykle trafia do bibliotek zakładowych. W ramach Wydziału Teologicznego działa 11 Zakładów wraz z odrębnymi bibliotekamis:

1.Zakład Katechetyki, Pedagogiki Chrześcijańskiej i Katolickiej Nauki Społecznej

2.Zakład Liturgiki i Homiletyki

3.Zakład Misjologii i Teologii Religii

4.Zakład prawa Kanonicznego

5.Zakład Teologii Biblijnej Starego i Nowego Testamentu

6.Zakład Teologii Dogmatycznej

7.Zakład Teologii Ekumenicznej

8.Zakład Teologii Fundamentalnej

9.Zakład Teologii Moralnej i Duchowości

10.Zakład Teologii Pastoralnej i Historii Duszpasterstwa

11.Zakład Teologii Patrystycznej i Historii Kościoła

${ }^{5}$ Działalność naukowa Wydziału Teologicznego Uniwersytetu Ślqskiego w Katowicach, w: Wydziat Teologiczny Uniwersytetu Ślaskiego w Katowicach w latach 2000-2005 (stan na 30 września 2005 roku), Katowice 2005, s. 203. 
Zaistniała obawa, że literature gromadzoną przez poszczególne zakłady trudno będzie wykorzystać dla szerszego grona czytelników. Dlatego ważną rolę odgrywa tworzenie przez Bibliotekę Teologiczną centralnego katalogu komputerowego, widocznego także w Internecie, w którym są rejestrowane wszystkie zakupione książki bez względu na miejsce ich przechowywania i udostępniania, a informacje o nich stają się łatwo dostępne dla wszystkich poszukujących.

Środki pochodzące z Kurii przeznaczane są przede wszystkim na zakup pozycji interdyscyplinarnych. Dzięki temu jest możliwe systematycznie uzupełnianie zarówno księgozbioru podstawowego, jak i podręcznego Czytelni Ogólnej o najnowsze słowniki, encyklopedie, leksykony, bibliografie oraz serie wydawnicze. $\mathrm{W}$ ten sposób gromadzona jest literatura przeznaczona na potrzeby studentów i zajęć dydaktycznych prowadzonych na Wydziale. Należy dodać, iż ze zbiorów Biblioteki Teologicznej korzystają również studenci innych wydziałów takich jak: Wydział Filologiczny, Wydział Nauk Społecznych, Wydział Prawa i Administracji, Wydział Pedagogiki i Psychologii oraz innych uczelni - Akademii Ekonomicznej, Akademii Muzycznej itp. Pokazuje to jak szeroki jest zakres tematyczny gromadzonego piśmiennictwa. Pieniądze pochodzące z Kurii Metropolitalnej wzbogacają również zakup archiwalny, który koncentruje się przede wszystkim wokół uzupełnianiu braków pozycji wielotomowych i serii naukowych.

\section{Polityka gromadzenia zbiorów}

Na politykę gromadzenia zbiorów zasadniczy wpływ wywierają pracownicy naukowo-dydaktyczni Wydziału Teologicznego. Przede wszystkim to kierownicy poszczególnych Zakładów w ramach swoich specjalizacji ustalają listy nabytków. Takie listy trafiają do Biblioteki, która następnie koordynuje cały proces zamawiania i zakupu. Często dzieje się tak, że to pracownicy Biblioteki docierają do informacji na temat nowości ukazujących się na rynku wydawniczym, a następnie przedstawiają sugestie ewentualnych zakupów naukowcom, którzy mogliby się nimi zainteresować. Do rozstrzygania jakichkolwiek wątpliwości dotyczących planowania poszerzania księgozbioru powołano organ doradczy w postaci Komisji Bibliotecznej, wybranej spośród pracowników naukowych macierzystego Wydziału.

Wobec bardzo szerokiej oferty wydawniczej, prezentowanej zarówno w tradycyjnych katalogach, jak i za pośrednictwem nowoczesnych nośników informacji $^{6}$ (Internet, CD-ROM-y), ważna staje się umiejętność doboru odpowiednich książek do zakupu. Obecnie bibliotekarz ma możliwość dotarcia do wielu źródeł informujących o publikacjach polskich i zagranicznych. Do najważniejszych tego rodzaju źródeł należą:

- tradycyjne katalogi wydawnicze i ksiegarskie,

- elektroniczne katalogi wydawnicze i księgarskie,

- księgarnie i hurtownie Internetowe,

${ }^{6} \mathrm{~A}$. Wysocki, Internet jako źródło informacji wydawniczej dla bibliotekarzy, „Bibliotekarz”, $6(2003)$ s. $19-23$. 
- egzemplarze okazowe,

- bibliografie,

- oferty wydawnicze drukowane w czasopismach lub przesyłane poczta elektroniczną ${ }^{7}$.

Pracownicy Biblioteki poszukując informacji dotyczących rynku wydawców literatury teologicznej korzystają najczęściej z takich serwisów informacyjnych jak:

- MATEUSZ Chrześcijański Serwis WWW' (www.mateusz.pl) - w którym od ponad 10 lat prezentowane są recenzje nowości oraz fragmenty książek wraz z możliwością dokonywania bezpośrednich zakupów poprzez księgarnię Internetową;

- Katolicka Agencja Informacyjna $\mathrm{KAI}^{9}$ (e.kai.pl) -będąc pierwszą i największą tego rodzaju agencją w Europie Środkowo-Wschodniej, od 1993 roku zapewnia dostęp do bieżących wiadomości dotyczących życia Kościoła i wszystkich dokumentów z tym związanych, a także rozprowadza książki wydawane $\mathrm{z}$ przy jej udziałem;

- Serwis Wydawców Katolickich ${ }^{10}$ (www.swk.pl) - stworzony przez Stowarzyszenie Wydawców Katolickich udostępnia informacje na temat wszystkich tytułów publikowanych przez wydawców działających w ramach Stowarzyszenia, dysponuje także bogatą bazą tele-adresową polskich oficyn diecezjalnych, zakonnych, akademickich oraz innych zajmujących się rozpowszechnianie literatury katolickiej;

- OPOKA ${ }^{11}$ (www.opoka.org.pl)- funkcjonuje od 1998 roku jako oficjalna witryna Kościoła Katolickiego w Polsce, która oprócz najświeższych informacji z życia Kościoła umożliwia poprzez swoją „Bibliotekę” dostęp do wielu interesujących dokumentów i artykułów na różnorodne tematy.

Równie ważna funkcję informacyjną pełnią targi ksiażki ${ }^{12}$. Każdego roku Biblioteka uczestniczy w takich imprezach jak: Targi Książki Katolickiej ${ }^{13}$, Międzynarodowe Targi Książki w Warszawie oraz Targi Książki w Krakowie. Stanowią one znakomitą okazję do zapoznania się z szeroką ofertą wydawniczą,

7 A. Muc, Współczesne formy reklamy ksiażki naukowej, „EBIB Elektroniczny Biuletyn Informacyjny Bibliotekarzy [online], 11 (2005) [dostęp: 10 III 2006], http://ebib.oss.wroc.pl/2004/59/ muc.php.

8 D. Górska, Przeglad Katolickich Serwisów Internetowych, „FIDES Biuletyn Bibliotek Kościelnych", 2 (1998) s. 27-44.

${ }^{9}$ R. Dunin, Strona internetowa Katolickiej Agencji Informacyjnej, „FIDES Biuletyn Bibliotek Kościelnych", 2(15) (2002) s. 97-98.

${ }^{10}$ R. Dunin, Serwis Wydawców Katolickich, „FIDES Biuletyn Bibliotek Kościelnych”, 2(15) (2002) s. 109-111.

${ }^{11}$ Górska, Przeglad, s. 32-35.

${ }^{12}$ J. Włodarczyk, Marketing targowy w trzech pigułkach, „Megaron”, 10 (1996) s. 20-22.

${ }^{13}$ A. Muc, Targi Wydawców Katolickich jako forma promocji ksiażki religijnej, „FIDES Biuletyn Bibliotek Kościelnych”, 1-2(18-19) (2001) s. 93-99; A. Wojtasik, Święto ksiażki katolickiej. IX Targi Ksiązki Katolickiej, „Gazeta Uniwersytecka. Miesięcznik Uniwersytetu Śląskiego w Katowicach”, 10 (2003) s. 14-15; A. Wojtasik, Szanse dla ksiqżki katolickiej, „Gazeta Uniwersytecka. Miesięcznik Uniwersytetu Śląskiego w Katowicach”, 8 (2003) s. 23. 
nowościami i zorientowania się $w$ planach wydawniczych wielu oficyn jednocześnie. Podczas spotkań z wystawcami można bezpośrednio złożyć zamówienia, kupić nowości po cenach promocyjnych, szczególnie takich firm, których publikacji brak w księgarniach. Niejednokrotnie w czasie rozmów udaje się także uzyskać tzw. egzemplarze gratisowe ${ }^{14}$. Ponadto w Bibliotece są organizowane wystawy książek zagranicznych, na które zaprasza się pracowników naukowych. Mogą oni wówczas zapoznać się z publikacjami, dokonać wyboru i złożyć zamówienie bezpośrednio w Bibliotece. Dotychczas głównymi organizatorami tego typu imprez były firmy pośredniczące w imporcie i dystrybucji zagranicznej literatury naukowej: International Publising Service oraz ABE Marketing ${ }^{15}$. Ponadto w 2005 roku na terenie macierzystego Wydziału odbył się I Kiermasz Wydawców Katolickich ${ }^{16}$. Podobnie jak wcześniej, tak i w tym przypadku dużym udogodnieniem było to, że wiele prezentowanych tytułów można było konsultować na bieżąco z pracownikami dydaktycznymi, którzy sugerowali właściwy zakup.

Biblioteka typując wydawnictwa do nabycia bierze pod uwagę także sugestie czytelników korzystających z jej usług. Bezpośredni kontakt z czytelnikami - studentami, doktorantami, pracownikami Wydziału - jak i ścisła z nimi współpraca oraz analiza częstotliwości wypożyczeń i rewersów w Wypożyczalni pozwalają na uwzględnienie i przewidywanie potrzeb użytkowników.

\section{Źródła zakupu literatury polskiej}

Rynek książki w Polsce pozostaje wciąż na tyle zróżnicowany i niezorganizowany, że aby zgromadzić odpowiednie piśmiennictwo, niezbędna jest współpraca $\mathrm{z}$ wieloma instytucjami, takimi jak hurtownie, księgarnie - również prowadzące sprzedaż wysyłkowa, wydawnictwa, czy inne firmy pośredniczące w procesie dystrybucji książek. Biblioteka dzięki temu, że nie jest finansowana tylko i wyłącznie przez Uniwersytet może sama wybierać dostawców literatury, ponieważ nie jest zmuszona do kierowania się procedurami zawartymi w ustawie „Prawo zamówień publicznych" ${ }^{17}$. Możliwość samodzielnego zakupu nowych zbiorów ułatwia realizację własnej polityki gromadzenia zbiorów, więc wartość takiego księgozbioru jest dużo większa dla czytelników aniżeli przypadkowe dary dla Biblioteki.

Obecnie najistotniejszą do rozstrzygnięcia kwestią jest to, jak składać zamówienia, mając na uwadze oszczędność i jednocześnie respektowanie istniejących

${ }^{14}$ W. Kapłan, E. Żelechowska, Problemy, doświadczenia i metody gromadzenia księgozbioru, ABMK, 62 (1993) s. 207-212.

15 B. Warząchowska, Wystawa naukowej ksiażki zagranicznej w Bibliotece Teologicznej, „Gazeta Uniwersytecka. Miesięcznik Uniwersytetu Śląskiego w Katowicach”, 4 (2003) s. 9.

${ }^{16}$ B. Warząchowska, Wystawy, kiermasze, targi - ksiażki do nas czy my do ksiażek, „FIDES Biuletyn Bibliotek Kościelnych", 1-2(18-19) (2001) s. 86-92.

${ }^{17}$ Por. Dziennik Ustaw nr 19 z dnia 9 lutego 2004 roku, pozycja 177, z późniejszymi zmianami; Sposób udzielania $i$ szacowania wartości zamówień przy zakupie ksiażek przez biblioteki. „Zamówienia Publiczne. Doradca: porady, interpretacje, wzory”, 3 (2005) s. 7. 
na rynku księgarskim poszczególnych sektorów. Pierwszym powodem decydującym o wyborze dostawcy jest wysokość uzyskiwanego rabatu, ale nie jest to warunek bezwzględny. „Oprócz zwykłego dostarczania zamówionych tytułów liczą się jeszcze takie elementy współpracy, jak: termin realizacji zamówień, dostarczanie informacji o nowościach, zamówieniach niezrealizowanych, transport na koszt firmy realizującej zamówienie, dostarczanie wcześniej egzemplarzy okazowych, które są podstawą do generowania zamówień. Ważna jest kultura współpracy, rzetelność dostawcy, brak pomyłek na fakturach, skrupulatność w obiegu dokumentów. Faktury kwalifikujące się do wycofania z powodu pomyłki wstrzymują proces przyjmowania i wprowadzania ksiazżek do systemu"18.

Różne sposoby dystrybucji powodują, że na rynku książka jest oferowana w zróżnicowanych cenach. Biblioteka zamawiając nowości zawsze poszukuje najtańszych ofert i stara się uzyskać korzystne rabaty. Dlatego znacząca część nabytków pochodzi z hurtowni ksiazżek katolickich "Emmanuel" w Katowicach, która systematycznie dostarcza egzemplarze okazowe i proponuje konkurencyjne ceny. Jest to bardzo korzystna forma współpracy, ponieważ wszyscy zainteresowani nowościami rynku książek katolickich mają możliwość przejrzenia każdej pozycji z autopsji na miejscu w Bibliotece, bez konieczności odwiedzania wielu księgarń. Na podobnej zasadzie odbywa się zamawianie literatury interdyscyplinarnej pochodzącej $\mathrm{z}$ różnych ośrodków naukowych w Polsce. W tym przypadku Biblioteka korzysta z usług Agencji Wydawniczej ,,a linea”, zajmującej się dystrybucją książek akademickich i naukowych na terenie całego kraju. Kilka razy w roku Agencja dostarcza kilkadziesiąt woluminów do wglądu, a po selekcji zabiera te które nie zostaną wytypowane do włączenia do księgozbioru. Taki sposób dokonywania zakupów pozwala nie tylko na dokładne zapoznanie się z poszczególnymi pozycjami, ale także w znacznym stopniu oszczędza czas i środki przeznaczane na opłaty pocztowe.

Oczywiście nie jest możliwa całkowita rezygnacja z nabywania książek w tradycyjnych księgarniach, zwłaszcza jeżeli zamawiającemu daną pozycję zależy na szybkim dostarczeniu konkretnego tytułu, albo jeżeli jest ona trudno dostępna. Zdarza się też tak, że jedynie w księgarni można kupić książki, których nakład został dawno wyczerpany lub wydawca już nie istnieje. W literaturze przedmiotu w ostatnim czasie można przeczytać o zmniejszającym się udziale sprzedaży książek w księgarniach ${ }^{19}$. Szacuje się, że , „1/3-" ksiŕýek z bieýŕcej produkcji wydawniczej rozchodzi sić rozmaitymi drogami pozaksićgarskimi" ${ }^{20}$. Również Biblioteka Teologiczna tylko sporadycznie korzysta z takiej formy sprzedaży. Stałą współpracę udało się jej nawiązać jedynie z Księgarnią Św. Jacka, która jest usytuowa-

18 E. Goumissi, Zakup ksiażek bezpośrednio u wydawcy - wybór czy konieczność? Charakterystyka dostaw literatury krajowej, „EBIB Elektroniczny Biuletyn Informacyjny Bibliotekarzy Materiały Konferencyjne" [online], 11 (2005) [dostęp: 10 III 2006], http://ebib.oss. wroc.pl/matkonf/grom2/goumissi.php.

${ }^{19}$ T. Nowak, Na ksiażkowym szlaku. Rzecz o dystrybucji, „Notes Wydawniczy”, 11 (2003) s. 42.

${ }^{20}$ C. Adamiec, Rynek ksiażki w Polsce, ,EBIB Elektroniczny Biuletyn Informacyjny Bibliotekarzy Materiały Konferencyjne" [online], 10 (2001) [dostęp: 10 III 2006], http://ebib.oss.wroc. $\mathrm{pl} / 2001 / 28 /$ adamiec.html. 
na najbliżej, a co najważniejsze od początku oferuje korzystne upusty na wszystkie kupowane książki. Oprócz tego pozycje wydawane przez Wydawnictwo św. Jacka, przy którym działa księgarnia, dostarczane są w postaci tzw. gratisów. W przeważającej części są to Silesiaki, stanowiące znaczną i ważną część zbiorów. Ostatnio Biblioteka nawiązała także współpracę z księgarnią Liber - działającą na terenie Uniwersytetu i zajmującą się rozprowadzaniem książek naukowych i akademickich publikowanych w wydawnictwach uczelnianych całego kraju.

Innym źródłem zakupu są księgarnie Internetowe, które proponują być może nie najtańszą ofertę (stosunkowo wysoki koszt przesyłki), ale na pewno najbardziej rozległą i urozmaiconą. Biblioteka korzysta $\mathrm{z}$ usług takich księgarń Internetowych jak:

- Główna Księgarnia Naukowa im. B. Prusa (www.gkn-prus.com.pl) - oferująca publikacje naukowe i popularnonaukowe, a także literaturę piękną polską i obcojęzyczna, książki o sztuce, albumy, wydawnictwa multimedialne oraz czasopisma polskie i obcojęzyczne pochodzące od ponad trzech tysięcy wydawców;

- Internetowa Ksiegarnia Akademicka IKA ${ }^{21}$ (www.ika.edu.pl) - powstała z inicjatywy Uniwersytetu Marii Curie-Skłodowskiej w Lublinie. Prezentuje i udostępnia dorobek edytorski oficyn wszystkich uniwersytetów polskich, przekazuje informacje o książce a zamówienie przesyła do konkretnego wydawcy;

- Księgarnia Mateusz ${ }^{22}$ (www.kmt.pl) - jest największą polską katolicką księgarnią Internetową i prezentuje bogatą ofertę większości wydawców chrześcijańskich działających na terenie Polski.

Profesjonalne księgarnie Internetowe, oprócz dużego asortymentu tytułów, proponują pełne i czytelne prezentacje każdej pozycji, zawierające recenzje, wywiady $z$ autorami, fragmenty książek, spisy treści oraz zdjęcia okładek ${ }^{23}$. Nie bez znaczenia pozostają także duże możliwości wyszukiwania według różnorakich indeksów i kategorii tematycznych. Jednak niewielkie możliwości negocjowania cen i rabatów powoduja, że taka forma zakupów jest ograniczana. Swoje strony oraz księgarnie Internetowe posiadają również poszczególne wydawnictwa, co jeszcze bardziej ułatwia dotarcie do poszukiwanych nowości.

Biblioteka prowadzi także zakup antykwaryczny starając się systematycznie i na bieżąco uzupełniać wszelkie braki zaistniałe w księgozbiorze. Dotarcie do pozycji wydanych wiele lat temu niejednokrotnie poprzedzają żmudne i długotrwałe poszukiwania, często zresztą bezowocne. Tego typu literatura jest kupowana $\mathrm{w}$ tradycyjnych antykwariatach, bądź za pośrednictwem Internetu. Obecnie w Polsce można dotrzeć do wielu stron WWW oferujących pozycje antykwaryczne, Biblioteka korzysta głównie z usług znanych i sprawdzonych, tj. Krakowskiego Antykwariatu Naukowego ${ }^{24}$, Antykwariatu Naukowego z Wrocławia ${ }^{25}$ oraz

${ }^{21}$ R. Dunin, Internetowa Księgarnia Akademicka - IKA, „FIDES - Biuletyn Bibliotek Kościelnych", 1(14) (2002) s. 120-122.

${ }^{22}$ R. Dunin, Katolicka księgarnia internetowa MATEUSZ, „FIDES - Biuletyn Bibliotek Kościelnych", 1(14) (2002) s. 123-125.

${ }^{23}$ K. Witkowski, Ksiqżka w Internecie, Warszawa 2000, s. 27.

${ }^{24}$ Tryb dostępu: http://www.antkrak.krakow.pl [dostęp: 10.03.2006].

${ }^{25}$ Tryb dostępu: http://www.antykwariat.art.pl [dostęp: 10.03.2006]. 
Antykwariatu Naukowego im. Jana Konstantego Żupańskiego z filiami w Poznaniu i Wrocławiu ${ }^{26}$.

\section{Zakup publikacji zagranicznych}

Dużą część zbiorów Biblioteki Teologicznej stanowią publikacje zagraniczne, które są systematycznie uzupełniane zarówno w nowości, jak i egzemplarze archiwalne. Jak dotąd wysokość wydatków na zakup literatury zagranicznej była porównywalna do wydatków przeznaczanych na książki polskie i stanowiła w przybliżeniu $47 \%$ wszystkich dotychczas wydanych środków. Tytuły zagraniczne są w większości kupowane z funduszy uniwersyteckich przeznaczonych na badania statutowe i własne.

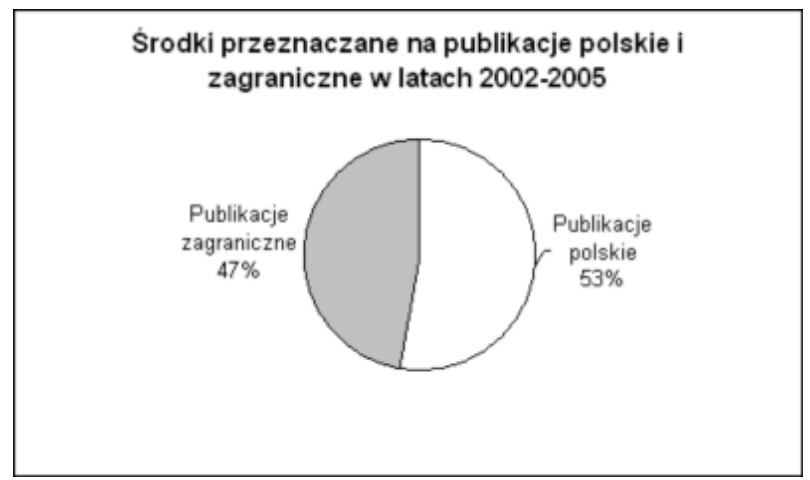

Oczywiście ceny książek zagranicznych są znacznie wyższe aniżeli polskich, dlatego ilościowy przyrost tego rodzaju publikacji jest zdecydowanie niższy i stanowi około $20 \%$ wszystkich zakupionych woluminów.

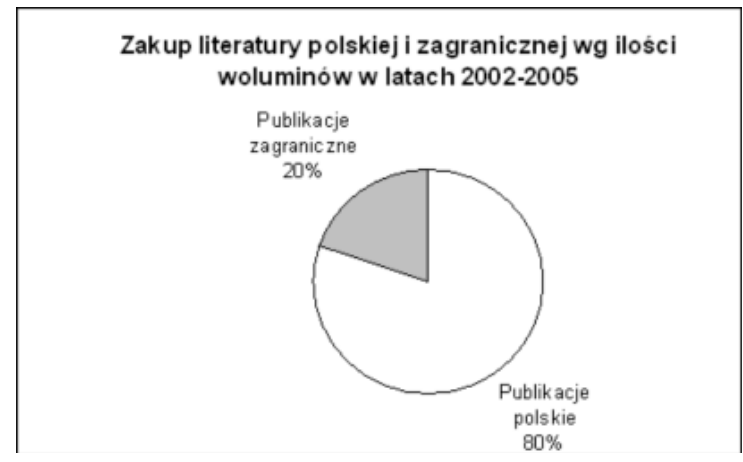

Zakup zagraniczny, podobnie jak polski odbywa się w dwojaki sposób: poprzez wybranego pośrednika oraz bez jego udziału, tj. bezpośrednio u wydawcy lub przez księgarnię Internetową. Biblioteka Teologiczna korzystając ze środków

${ }^{26}$ Tryb dostępu: http://www.antykwariat.pl [dostęp: 10.03.2006]. 
Uniwersytetu Śląskiego jest zobligowana do kupowania literatury obcojęzycznej przez firmy zajmujące się importem publikacji. Z praktyki okazuje się bowiem, że ten sposób zakupów bardziej opłaca się bibliotekom niż bezpośrednie dostawy od wydawców. Dzieje się tak, gdyż do ceny katalogowej każdej książki sprowadzanej bezpośrednio przez bibliotekę należy doliczyć dodatkowe opłaty na koszty wysyłki pocztowej oraz przelewu bankowego (notowano już przypadki gdy opłaty za operacje bankowe przekraczały wartość zamawianych książek). Obowiązkowo dochodzą do tego koszty telekomunikacyjne oraz nierzadko opłaty za usługi agencji celnej obsługującej przesyłkę ${ }^{27}$. Pośrednicy natomiast na ogół sprzedają bibliotekom po cenie katalogowej książki publikowane przez duże profesjonalne wydawnictwa, a takie pozycje stanowią znaczną część gromadzonej literatury zagranicznej. Co prawda nie udaje się jednak u pośredników uzyskać cen katalogowych dla tytułów publikowanych przez małe wydawnictwa, ale w tym przypadku również biblioteka nie uzyska niższej ceny zakupu, co potwierdzają badania naukowe przeprowadzane w Polsce w bibliotekach naukowych ${ }^{28}$.

Biblioteka Teologiczna obecnie korzysta $\mathrm{z}$ usług czterech wypróbowanych pośredników: ABE Marketing, KUBICZ Book Center, Wydawnictwo Importowane OMEGA PRESS oraz International Publising Sernice. Są to firmy działające na polskim rynku od kilkunastu lat. Zajmują się importem wszystkich typów publikacji naukowych (książki, CD-ROMY, multimedia, czasopisma) z całego świata.

Mając na uwadze wysokie ceny obcojęzycznej literatury naukowej Biblioteka stara się najpierw sama sprawdzić cenę u wydawcy albo też wysyła zapytanie o cenę do różnych pośredników, a następnie wybiera najkorzystniejszą ofertę. Czasami rozpiętość cenowa tego samego tytułu bywa zaskakująco wysoka. Pomimo, że zamawianie pozycji zagranicznych poprzez firmy pośredniczące znacząco zmniejsza wkład pracy bibliotekarza $\mathrm{w}$ proces zamawiania, to jednak Biblioteka stara się także sama nawiązywać współpracę bezpośrednio z wydawnictwami i indywidualnie negocjować ceny. Oczywiście pociąga to za sobą konieczność ciagłego dokształcania się w zakresie znajomości języków obcych i prowadzenia korespondencji obcojęzycznej, ale efekty bywają imponujące - nawet kilkudziesięcioprocentowe upusty. Kilka lat temu podczas Międzynarodowych Targów Książki w Warszawie, Bibliotece udało się nawiązać kontakt z niemieckim wydawnictwem Walter de Gruyter. Dzięki przeprowadzonym wówczas rozmowom i negocjacjom stał się możliwy zakup wielu pozycji po bardzo atrakcyjnych cenach (niektóre nawet z 50\% upustami), w dodatku bez konieczności uiszczania opłat za transport i przelewy bankowe. Bowiem finalizowanie zamówień, czyli przekazywanie pieniędzy i odbiór książek, odbywały się podczas Targów. Ostatnio udało się nawiązać współpracę na równie korzystnych warunkach z belgijskim wydawnictwem Brepols. Stało się to możliwe, ponieważ Biblioteka Teologiczna należy do Federacji Bibliotek Kościelnych „FIDES” działającej w ramach Stowarzyszenia Europejskich Bibliotek Teologicznych „BETH”.

${ }^{27}$ M. Lewison, O dostawcach publikacji importowanych, „Notes Wydawniczy”, 12 (1998) s. 41.

${ }^{28}$ U. Wojtasik, Zakup oraz wykorzystanie ksiażek zagranicznych w bibliotekach akademickich, „Przegląd Biblioteczny”, 3 (1999) s. 157-166; U. Wojtasik, Zakup ksiażek zagranicznych dla bibliotek akademickich, „Bibliotekarz”, 6 (1998) s. 5-7 . 
Wydawnictwo zaproponowało wszystkim członkom Federacji 25\% rabat na wyjątkowo wartościowe materiały źródłowe, dostępne w niewielu miejscach w Polsce. W ten sposób uda się uzupełnić m.in. obszerną serię naukową Corpus Christianorum.

Całe kolekcje tekstów źródłowych bywają także gromadzone w wersji elektronicznej, jak chociażby obszerne teksty łacińskie oraz greckie są dostępne na CD-ROM-ach (Library of Latin Texts, Lector 2003). Stanowią one niezwykle efektywne, szybkie, wygodne i bezpieczne źródła wiedzy i dlatego są coraz częściej poszukiwane przez czytelników. Biblioteka Teologiczna wychodząc na przeciw oczekiwaniom swoich użytkowników stara się systematycznie powiększać zasób dokumentów elektronicznych ${ }^{29}$. Taka forma gromadzenia zbiorów niesie za sobą wiele udogodnień dla czytelników, ale także pozwala zaoszczędzić powierzchnię magazynową w Bibliotece.

\section{Warsztat gromadzenia zbiorów}

Bibliotece Teologicznej przez pięć lat swojej działalności udało się stworzyć sprawnie funkcjonujący warsztat gromadzenia zbiorów ${ }^{30}$, będący nieodzownym elementem każdej dobrze działającej książnicy akademickiej. W jego skład wchodzą odpowiednio dobrany księgozbiór podręczny, różnego rodzaju kartoteki oraz centralny katalog komputerowy. Księgozbiór podręczny zawiera wybrane wydawnictwa encyklopedyczne - głównie z zakresu wiedzy o książce oraz teologii, literaturę fachowa, informatory o bibliotekach, instytucjach wydawniczych oraz kościelnych, księgarniach, a także pozycje będące źródłami informacji bibliograficznej o piśmiennictwie.

Do najważniejszych kartotek warsztatu gromadzenia zbiorów należą kartoteka zakupu oraz kartoteka kontynuandów. Kartoteka zakupów zawiera wszystkie zamówienia składane przez pracowników naukowo-dydaktycznych wraz z adnotowanymi opisami bibliograficznymi książek oraz informacjami dotyczącymi instytucji, w których poszczególne pozycje zostały zamówione. W tym miejscu odnotowuje się również datę złożenia zamówienia, ilość egzemplarzy i dla kogo są one przeznaczone, może to być Czytelnia Ogólna, Wypożyczalnia, czy któryś z Zakładów. Uzupełnianie zbiorów i przede wszystkim szybkie zorientowanie się w brakach, występujących głównie wśród wydawnictw seryjnych, może ułatwić kartoteka kontynuandów. Odnotowuje się w niej przede wszystkim te wydawnictwa seryjne lub zwarte wielotomowe, których kompletowanie sprawia wiele kłopotu, bo albo ukazują się nieregularnie, albo też następujące po sobie tomy czy części nie wychodzą kolejno. W tego rodzaju kartotece odnotowuje się ile egzemplarzy danego tytułu jest kupowanych i dla kogo, jak i wszelkie dane dotyczące oficyny wydającej kompletowany tytuł.

Biblioteka dokonując zakupu literatury nawiązała współpracę z tak wieloma instytucjami z Polski i z zagranicy, że konieczne stało się stworzenie rozbudo-

${ }^{29}$ J. Latawiec, Dokument elektroniczny w bibliotece, ABMK, 83 (2005) s. 171-180.

${ }^{30}$ Bibliotekarstwo, red. Z. Żmigrodzki, s.55. 
wanej kartoteki adresowej z księgarniami, wydawcami, hurtowniami, dystrybutorami itd. , której zawartość jest na bieżąco modyfikowana i uzupełniana. Poza tym stworzono kartotekę $\mathrm{z}$ adresami e-mail pracowników naukowo-dydaktycznych $\mathrm{w}$ celu usprawnienia prowadzonej korespondencji dotyczącej generowania zamówień. Dodatkowo zredagowano szablony zamówień w języku polskim oraz językach obcych, co wpłynęło na skrócenie czasu i zmniejszenie wkładu pracy potrzebnego do tworzenia kolejnych zamówień i koordynowania procedury zakupu literatury. Wszystkie dotychczasowe doświadczenia w nabywaniu nowości pozwoliły na wypracowanie odpowiedniej strategii gromadzenia zbiorów, opartej na zaspokajaniu potrzeb czytelników oraz analizie możliwości finansowych Biblioteki.

\title{
DER ANKAUF VON BÜCHERN DURCH DIE THEOLOGISCHE BIBLIOTHEK DER SCHLESISCHEN UNIVERSITÄT
}

\begin{abstract}
Zusammenfassung
Der Ankauf, der Tausch und das Pflichtexemplar bilden die Grundformen der Entwicklung des Bibliotheksbestandes. Der Ankauf ist in der Theologischen Bibliothek der Schlesischen Universität die zweitgrößte, neben des Tausches und der Schenkungen, Form der Gewinnung der Dokumente. Er ist durch zwei unabhängige Finanzierungsquellen bedingt. Der Großteil der finanziellen Mittel stam$\mathrm{mt}$ aus dem Ordinariat der Erzdiözese Katowice und ist für die Erweiterung des Grundbestandes und des Handapparats im Lesesaal bestimmt. Mit Hilfe der aus der Universität stammenden Mittel wird die spezialistische Literatur erworben, die für die an der Theologischen Fakultät geführte Forschung notwendig ist. Die Politik der laufenden Erwerbungen wird von den wissenschaftlichen Mitarbeitern der Universität, in enger Zusammenarbeit der Bibliothekangestellten gestaltet. Der Vorgang der Bestellung selbst wird von den Bibliothekaren durchgeführt und koordiniert. Auf den Bestelllisten befinden sich sowohl polnische als auch fremdsprachige Titel, die sowohl in der traditionellen Buchform wie auch in der elektronischen Form herausgegeben sind. Die Bibliothek verfügt über die Möglichkeit des selbständigen Ankaufs der neu erschienenen Titel und der Wahl der Ankaufsquelle. Das erleichtert die Erweiterung der Buchsammlung und beschleunigt sie wesentlich.
\end{abstract}

